International Business Management 13 (3): 77-84, 2019

ISSN: $1993-5250$

(C) Medwell Journals, 2019

\title{
Challenges in Marketing the Agricultural Product (The Case of Libya)
}

\author{
Khairi Mohamed Omar \\ College of Administrative Sciences, Applied Science University, Al Eker, Bahrain
}

\begin{abstract}
All around the globe there is a recession is going on and it hits even in the Middle East countries which are oil rich nations. This case is based on Libyan marketing agricultural challenges and barriers. It will be examined the issues and what are the reasons behind as well as the challenges and barrier issues which facing the new young Libyan government which can influence non-oil Libyan marketing product among and outside the country. This case study aims to analyze the above mentioned problems and hopefully will come up with comprehensive recommendations to its solutions using the concepts and marketing strategies.
\end{abstract}

Key words: Libya, marketing, agricultural, olive, olive oil, dates

\section{INTRODUCTION}

The Libyan economy is one of the least diversified markets in the world. The sharp recovery in oil production is clearly the main driver of headline growth in the near term. According to estimates by the IMF (2012), hydrocarbons account for $70 \%$ of GDP, more than $95 \%$ of exports and $90 \%$ of government revenues. While this underscores the lack of development in the non-hydrocarbon economy and raises questions about whether any new government will be able to make significant headway in bolstering the private sector, it also provides a degree of solace that 2011's contraction will prove only temporary. Given that, the hydrocarbon sector is not a major employer the massive ramp-up in production and exports the year of 2012 will be unlikely to translate into a marked improvement in living standards in the near term.

Therefore while consumer spending within food and drink is still expected to grow quite strongly in 2013, it is also true that a lot of this growth is coming from a low base. The rising questions are new Libyan young generation leaders will be able to catch up with the wider world market and what are the opportunities for new entry player's corporations either national or international?

Brief history of the country: Libya declared its independence from Italy in 1951 as a constitutional monarchy. After the discovery of oil in 1959 and the subsequent increase in the country's economic fortune, popular discontent grew as a result of the high degree of wealth concentration among the country's elite. In 1969 , a military coup led by Muamar ElQadafi, overthrew the

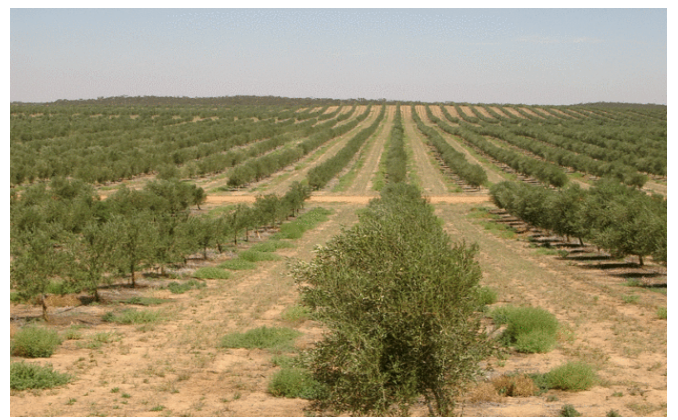

Fig. 1: One of Libyan olive oil farms

monarchy and declared the country a people's republic. Following several state sponsored acts of terrorism against Western targets abroad, the UN imposed sanctions on Libya in 1992. As a result, the country was largely isolated from the world, economically and politically all throughout the nineties. Between 1999 and 2003, the Libyan government took steps to lift the sanctions including handing over Libyan suspects for international trial and paying compensation to the victims. UN sanctions were consequently removed in 2003 and the country. In 17th of February 2011, the revolution took place and the young new leaders came to the power (CFR., 2005; EIA., 2014; Anonymous, 2015, 2016) (Fig. 1).

In terms of agriculture, according to the Anonymous (2006), although, of the fact that Libya imports about $75 \%$ of its food, the country has good climatic conditions which can make the agriculture sector as the second sector after the oil production. Table 1 displays the Libyan Gross Domestic Product GDP 2004-2013.

Corresponding Author: Khairi Mohamed Omar, Department of Business Administration, College of Administrative Sciences, Applied Science University, Al Eker, Kingdom of Bahrain 
Int. Business Manage., 13 (3): 77-84, 2019

\begin{tabular}{|c|c|c|c|c|c|c|c|c|c|c|}
\hline Variables & 2004 & 2005 & 2006 & 2007 & $2008 \mathrm{f}$ & $2009 \mathrm{f}$ & $2010 \mathrm{f}$ & $2011 \mathrm{f}$ & $2012 \mathrm{f}$ & $2013 \mathrm{f}$ \\
\hline Nominal GDP LYDbn & 41.500 & 56.000 & 61.800 & 69.400 & 80.000 & 89.500 & 98.700 & 108.700 & 119.200 & 128.200 \\
\hline Nominal GDP U\$\$bn & 33.190 & 41.460 & 48.180 & 56.780 & 64.020 & 68.910 & 73.530 & 80.960 & 88.820 & 95.490 \\
\hline Real GDP growth, percentage change $y-0-y$ & 5.300 & 5.500 & 6.800 & 5.200 & 5.700 & 5.500 & 7.100 & 6.900 & 6.500 & 4.400 \\
\hline GDP per capita U\$\$ & 5.722 & 7.003 & 7.976 & 9.218 & 10.198 & 10.774 & 11.282 & 12.189 & 13.123 & 13.860 \\
\hline Population, MM & 5.800 & 5.920 & 6.040 & 6.160 & 6.280 & 6.400 & 6.520 & 6.640 & 6.770 & 6.890 \\
\hline
\end{tabular}

Country authorities and IMF staff estimates (2012)

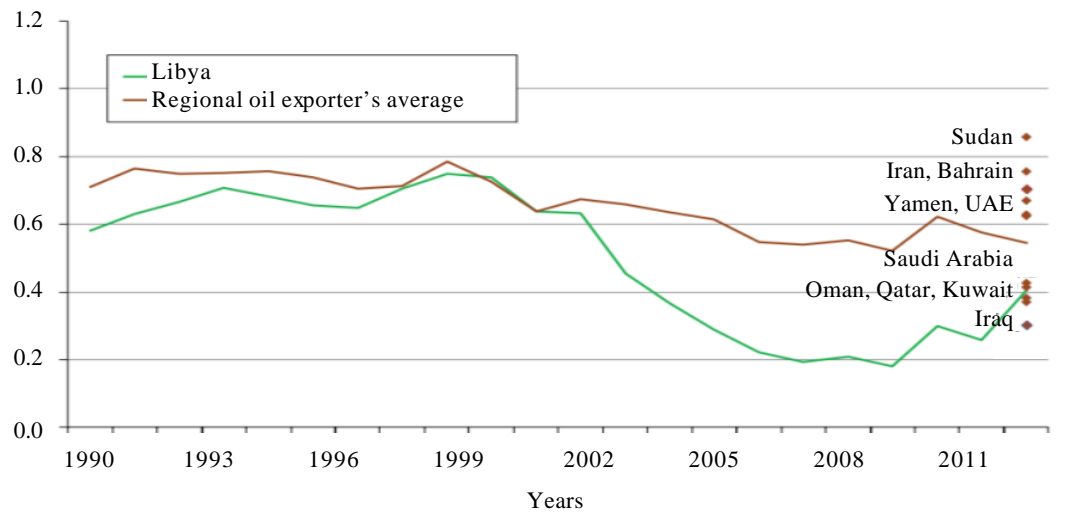

Fig. 2: Libya Ranks among the most hydrocarbon-dependent countries (ratio of non-hydrocarbon GDP to total GDP); Country authorities and IMF staff estimates (2010)

\section{MATERIALS AND METHODS}

Libya market and problems in marketing their agricultural product (olive, olive oil and dates case): Agricultural production is dominated by crop production which account for $5 \%$ of the Gross Domestic Product (GDP) and occupies about $13 \%$ of the total labour force. The total arable land is about 2,170,000 ha of which 355,000 ha are permanent crops. The permanent pasture and rangeland occupy about $13,300,000$ ha and the forest and woodland about 320,000 ha. The agriculture productions are depending mainly on the private sector. The private farms owned by individuals are producing the biggest part of the agricultural product. Some government production projects were established under irrigation in the desert, mainly for cereal and forage production (Al-Idrissi et al., 1996) (Fig. 2).

\section{The most important agricultural in libya stated:}

Barley and wheat

- Tomato, potato and onion

- Olive and olive oil

. Dates

. Vegetables

. Fruits

. Meat (Anonymous, 2015)

According to the census survey in 2000, Libya has more than 12 million olive trees and the rate of production of the year 2000-2001 was approximately 157.5 thousand tons of the olive. The swab planted olives in Libya about 280,000 ha on the grounds which means 25 trees per ha (Anonymous, 2006). According to Food and Agriculture Organization (FAO) in 2010, Libya ranks eleventh in the world as a producer of olive along with Spain, Italy, Greece, Tunisia, Egypt and Portugal Table 2 illustrate that expansion of agriculture products generally and in particular olive growing in Libya in the last few years has been mainly by the private sector. Most of the old olive plantations are mixed with other crops. However, recently farmers started to establish solid olive plantations whenever they have irrigation water. The olive and dates Trees farms in the coastal belt, especially in the western part of the country, areas between olive and dates trees can be used for cereal production (barley) and vegetable crops if irrigation is available (Fig. 3).

However, in regards to the institutional arrangements relating to irrigation water it mainly operated by the management of irrigation facilities and systems which was in somehow and still controlled by the government agencies or central departments as it happened in many Arab countries manage irrigation networks. However, these networks suffer from poor maintenance and mismanagement due to lack of proper staff. These in fact, this lack of proper staff and good management has affected not only on the the institutional arrangements relating to irrigation water but also on the other aspects of infrastructure for irrigation (Kubursi, 2012) (Table 3 and 4). 
Int. Business Manage., 13 (3): 77-84, 2019

Table 2: Main countries of production (Year 2010 per FAOSTAT)

\begin{tabular}{llccr}
\hline Ranks & Countries/regions & Production (In tons) & Cultivated area (In ha) & Yield (Q/ha) \\
\hline 01 & Spain & $8,014,000$ & $2,092,800$ & 38.293 \\
02 & Italy & $3,170,700$ & $1,190,800$ & 26.627 \\
03 & Greece & $1,809,800$ & 834,200 & 21.695 \\
04 & Morocco & $1,483,510$ & 735,400 & 20.173 \\
05 & Turkey & $1,415,000$ & 826,199 & 17.127 \\
06 & Syria & 960,400 & 647,500 & 14.832 \\
07 & Tunisia & 876,400 & $1,645,100$ & 5.327 \\
08 & Egypt & 611,900 & 128,700 & 47.545 \\
09 & Algeria & 555,200 & 316,300 & 17.553 \\
10 & Portugal & 239,600 & 250,200 & 9.576 \\
11 & Libya & 180,000 & 205,000 & 8.780 \\
12 & United States & 172,370 & 13,354 & 129.077 \\
13 & Jordan & 171,672 & 60,879 & 28.199 \\
14 & Argentina & 165,000 & 55,700 & 29.623 \\
15 & Palestine & 99,000 & 108,100 & 9.158 \\
16 & Lebanon & 97,600 & 62,500 & 15.616 \\
& World & $20,578,186$ & $9,398,623$ & 21.985 \\
\hline
\end{tabular}

Food and Agriculture Organization (2010)

Table 3: Liby a agricultural vs. Tunisia agricultural

\begin{tabular}{|c|c|c|c|c|c|c|c|c|c|c|c|c|c|}
\hline \multicolumn{4}{|c|}{ Description } & \multicolumn{5}{|c|}{ Libyan agriculture stats } & \multicolumn{5}{|c|}{ Tunisia agriculture stats } \\
\hline \multirow{2}{*}{\multicolumn{4}{|c|}{ Agricultural growth }} & \multicolumn{5}{|c|}{129} & \multicolumn{5}{|c|}{120} \\
\hline & & & & \multicolumn{5}{|c|}{ Ranked 27 th. $8 \%$ more than Tunisia } & \multicolumn{5}{|c|}{ Ranked 47th } \\
\hline \multirow{2}{*}{\multicolumn{4}{|c|}{ Arable and permanent cropland }} & \multicolumn{5}{|c|}{2,150 thousand ha } & \multicolumn{5}{|c|}{5,014 thousand ha } \\
\hline & & & & \multicolumn{5}{|c|}{ Ranked 83rd } & \multicolumn{5}{|c|}{ Ranked 43rd. $133 \%$ more than Libya Arable land } \\
\hline \multicolumn{4}{|c|}{ Arabic land hectares } & \multirow{2}{*}{\multicolumn{5}{|c|}{$1,815,000$ ha }} & \\
\hline & & in 2003 & & & & \multirow{2}{*}{\multicolumn{5}{|c|}{ Ranked 67 th in $2003.54 \%$ more than Liby a }} \\
\hline & & & & \multicolumn{5}{|c|}{$1.03 \%$ of land area } & & & & & \\
\hline \multicolumn{4}{|c|}{ Arable land $\%$ of land area } & \multicolumn{5}{|c|}{ Ranked 183 rd in 2003} & \multicolumn{5}{|c|}{ Ranked 62 nd in 2003.16 times more than Libya } \\
\hline Cereal prod & ion & & & 129 thou & $\mathrm{d}$ metric $\mathrm{t}$ & & & & $120 \mathrm{t}$ & usand me & tons & & \\
\hline & & & & Ranked 2 & $.8 \% \mathrm{mor}$ & $\operatorname{lan}$ Tunis & & & Rank & 47 th & & & \\
\hline Crop produ & on index & & & $99.8 \%$ & & & & & 101.7 & & & & \\
\hline & & & & Ranked 1 & th in 2004 & & & & Rank & $123 r d$ in & 4. $2 \% \mathrm{~m}$ & e than $\mathrm{L}$ & bya \\
\hline Fertilizer us & & & & $26.5 \mathrm{~kg}$ & & & & & 22.2 & & & & \\
\hline & & & & Ranked \& & 1. $19 \% \mathrm{~m}$ & than Tun & & & Rank & 90th & & & \\
\hline Food produ & on index & & & $104.3 \%$ & & & & & 101.6 & & & & \\
\hline & & & & Ranked 1 & nd in 200 & $\%$ more & n Tunisia & & Rank & 129 th in & & & \\
\hline Labour shat & & & & $5.6 \%$ & & & & & $24.3^{\circ}$ & & & & \\
\hline & & & & Ranked 1 & & & & & Rank & 79th. $3 \mathrm{t}$ & more th & a Libya & \\
\hline Livestock $\mathrm{p}$ & luction in & & & $100.9 \%$ & & & & & $98.8^{\circ}$ & & & & \\
\hline & & & & Ranked 1 & th in 2004 & $\%$ more $t$ & Tunisia & & Rank & 150 th in & & & \\
\hline Permanent & & & & 335,000 & tares & & & & 2,105 & 00 ha & & & \\
\hline & & & & Ranked S & & & & & Rank & 16th. $5 \mathrm{t}$ & more th & L Libya & \\
\hline Root and tu & product & & & 205 thou & d metric $t$ & & & & $311 \mathrm{t}$ & usand me & tons & & \\
\hline & & & & Ranked 1 & & & & & Rank & 102nd. 5 & more the & Libya & \\
\hline Value adde & nnual gro & th $\%$ & & $-3.72 \%$ & & & & & 12.86 & & & & \\
\hline & & & & Ranked 1 & th in 198 & & & & Rank & 19 th in 1 & & & \\
\hline Value adde & urrent US & (per ca & ita) & $288.7 \mathrm{Sp}$ & capita & & & & 207.8 & per capit & & & \\
\hline & & & & Ranked 3 & 1987. & $\%$ more $t$ & Tunisia & & Rank & 64th in 1 & & & \\
\hline Workers pe & & & & 0 & & & & & 0.2 & & & & \\
\hline & & & & Ranked 1 & & & & & Rank & 105th & & & \\
\hline http://www & ricultur & $\mathrm{m}(20$ & & & & & & & & & & & \\
\hline Countries & 1990 & 1991 & 1992 & 1993 & 1994 & 1995 & 1996 & 1998 & 1999 & 2000 & 2001 & 2004 & 2010 \\
\hline Tunisia & 660.0 & 839.0 & 1340.0 & 688.0 & 1063.0 & 350.0 & 300.0 & 450.0 & 900.0 & 1125.0 & 550.0 & 355.0 & 450.6 \\
\hline Algeria & 177.9 & 88.0 & 266.0 & 206.0 & 170.4 & 131.0 & 313.3 & 124.1 & 363.4 & 298.3 & 200.3 & 319.5 & 239.8 \\
\hline Palestine & 75.0 & 70.0 & 80.0 & 79.0 & 83.7 & 44.1 & 130.5 & 91.9 & 35.4 & 149.6 & 148.6 & 96.7 & 667.9 \\
\hline Libya & 68.0 & 70.0 & 168.8 & 186.6 & 168.8 & 168.8 & 185.7 & 185.9 & 275.0 & 165.0 & 150.0 & 140.0 & 180.0 \\
\hline Lebanon & 62.0 & 43.8 & 103.1 & 60.5 & 77.9 & 38.7 & 96.5 & 67.1 & 66.4 & 189.5 & 85.8 & 38.6 & 30.8 \\
\hline Iraq & 5.0 & 3.0 & 5.0 & 3.0 & 3.0 & 3.0 & 5.0 & 4.0 & 4.0 & 6.0 & 6.0 & 4.0 & 3.2 \\
\hline Kuwait & 0.0 & 0.0 & 0.4 & 0.0 & 0.0 & 5.6 & 5.1 & 0.0 & 0.0 & 0.0 & 0.0 & 0.0 & 1.0 \\
\hline
\end{tabular}

World Bank Document website (2012) 


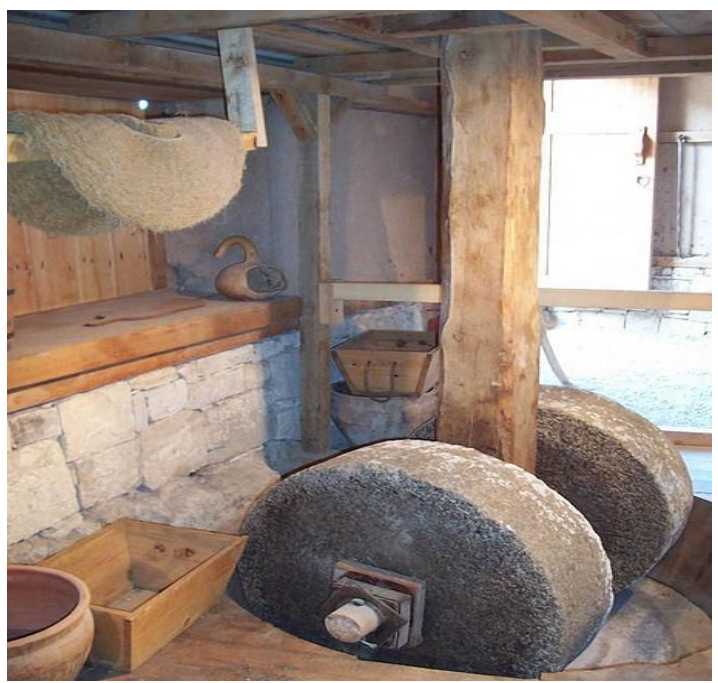

Fig. 3: Old olive oil extraction machine (oil-press)

\section{RESULTS AND DISCUSSION}

Issues: The change in the Arab world and in specifically Libya, especially after entering the wave of openness to the outside world, this openness has made the global environment widely shared environment and then has resulted in a whole big change in the customers testing and requests increasingly by them. This in addition to the rule of an atmosphere of intense competition that cannot be staying only for the institutions capable of diagnosing this environment and by the discovery of the hopes and aspirations of customers. Under this topic, changes found marketing positions within the organization and its importance in achieving its goals and is promoting one of the elements of the marketing mix which ensures transmission of information to and from the institution and it touches on this topic study to some marketing concepts generally as one approaches the institution of modern economic and devote part to talk about promotion and challenges in terms of concept, elements as one of the marketing policies to contribute and great doubt in events communicates with the enterprise environment. Also, the path form of success through agricultural production marketing can be through several methods which are missing in the case of Libya.

Marketing of agricultural products (dates, olives and olive oil): Generally, agricultural and industrial production in Libya is suffering from many problems and limitations which can be classified into: environmental problems, technical and human error problems, economic problems and legislative problems. Below follows a brief account of the most important problems and limitations faced by the agriculture sector development of olives, olive oil and dates in Libya.

Environmental factors: There are several specific environmental factors that are considered for the cultivation of olives, olive oil and dates which can be summarized. The amount and distribution of rainfall during the fall and winter for instance, especially in the case of non-availability of supplementary irrigation in drought years. Years of drought in which at least rainfall $(200 \mathrm{~mm})$ do not adversely affect production only but also the survival of the trees themselves. In such years, it becomes necessary to give supplementary irrigation for trees, especially small ones which did not consist of total forces after pox. Also, soil suitable for olive cultivation, despite the fact that the olive trees grow in most soils in varying degrees but the clay soil rich are best suited to olive trees in order to give economic effect is good.

Economic factors: Thus, economic factors may be the primary determinant for the success of any economic activity. In the field of agriculture and industry in Libya there have been several economic determinants, among them the production and price fluctuations from year to year and limit of embarking upon farmers to expand in agriculture. Also, the high cost of production inputs (agricultural operations and extraction) where sometimes equal to or more than the income earned forcing farms to the neglect of trees and not to serve its requires support cut the price of farm inputs and determine an appropriate price for the purchase of surplus crop. At the level of promotion; Inability to influence in Foreign markets for Libyan products in spite of the efforts made in the field of development exports of olive oil for instance.

Technical factors: Despite the great expansion of agriculture (e.g., dates and olive products) and industrial products in the country but it still suffers from several technical problems such as inadequate scientific research and formal scientific recommendation, especially in the field of marketing. Where using inappropriate containers to transfer dates and olive and the absence of plastic bottles to fill olive-oil for consumer. As well as the absence of different marketing information including consumer's desires and needs of export markets and prices in those markets and other information that will help producers and investors to make sound decisions and the lack of consumer awareness in terms of quality. All of these factors are the main reasons that hold the development of Libyan market. 
Marketing mix systems for dates, olives and olive oil in Libya: Marketing system consists of four sub-systems which on the whole marketing system for any commodity. These systems are the production and distribution system, consumption and regulation.

Produces issues: The system is characterized by the production of olives and dates in the Libya adoption of a large proportion of the space directly on rain-fed agriculture which vary from year to year which affects the annual production volume and the proportion of dates, olives and olive oil extracted from the fruit. As characterized by low production efficiency due to the small size of holdings and the failure to follow scientific methods in agriculture and lack of attention by producer service operations and the lack of proper use of fertilizers and lack of irrigation sources for supplemental irrigation purposes.

Promotion and consumption issues: The promotion system is still at the beginning stages and marketing and promotion efforts are restricted in most of the Arab countries especially in the case of Libya. There is a lack of consumer marketing education efforts, especially with respect to storage, consumption and the nutritional importance of dates and olive oil. And that are associated with low efforts in promoting and the absence of regulatory institutions to the private sector the quality and cooperatives and the national authorities which holds the affairs of this sector and the weakness of official government efforts in the field of promotion due to the high mandated.

Distribution issues: The distribution system can be characterized as primitive system and that's because it works in isolation from the global market and daily developments on the one hand and the absence of active institutions and companies which specializing in marketing. Production is marketed in bulk lacking value added such as packaging in smaller containers which may be due in part to the absence of appropriate containers where fresh fruit is marketed in plastic bags or plastic containers or polystyrene containers that may lead to damage fruit.

The distribution system also lacks of qualified mediators and appropriate contemporary markets with high efficiency. Due to the scattered and small size of holdings and perhaps lack of conviction cooperative action, it could be argued that Libya is almost devoid of any appropriate productive organizations and/or active marketing in the production and marketing of dates, olives and olive oil and agricultural product generally. Elaboration process of table olives and dates (Fig. 4).
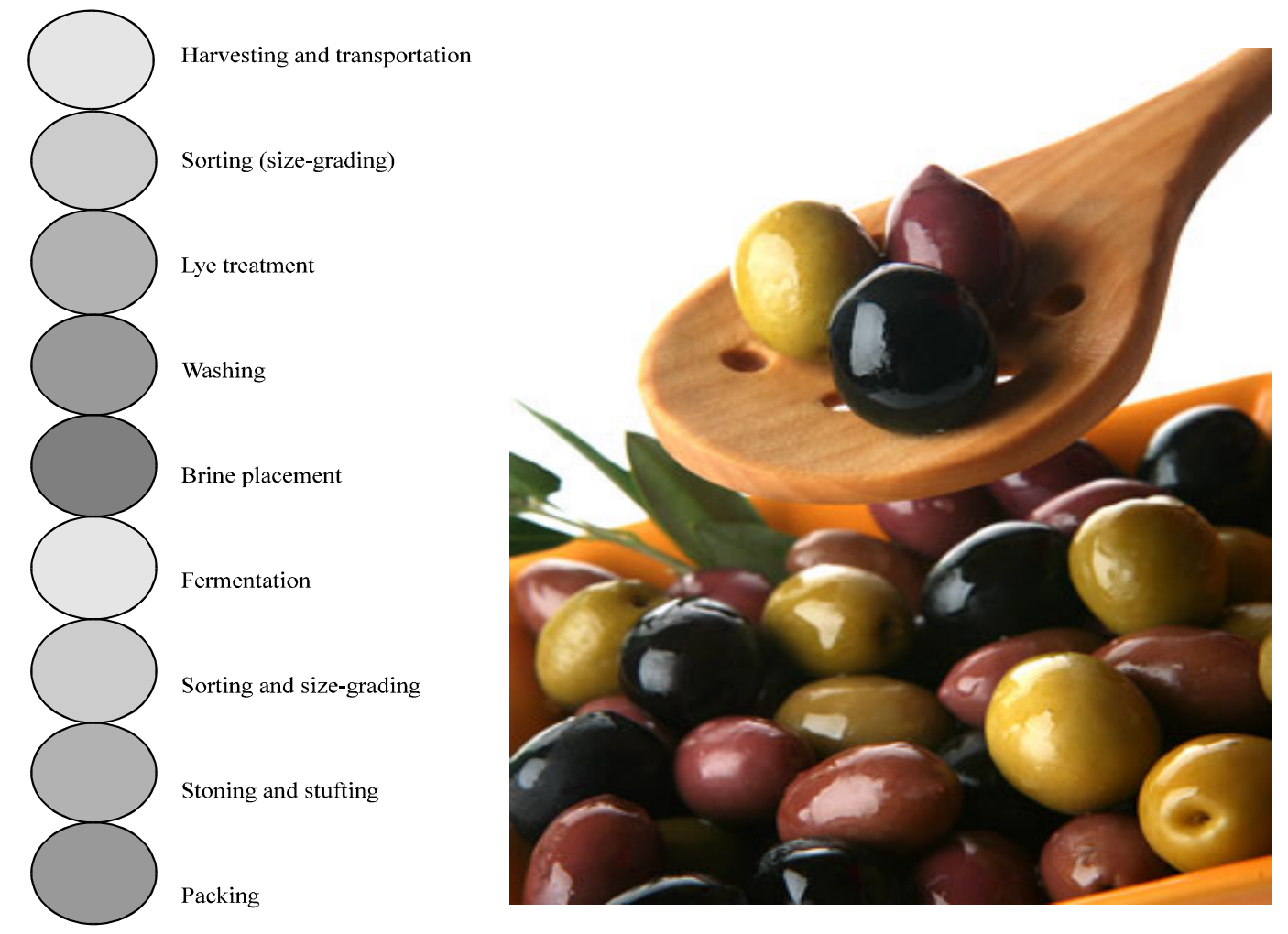

Fig. 4: Elaboration process of table olives and dates 
Organization: In terms of organization there is no effective state regulation in terms of producers, manufacturers or marketers. There is a low degree of coordination and cooperation between producers and that may be attributable to the small size of holdings and scatter them as well as the lack of convincing usefulness of teamwork to the producers. Also, there are still no effective qualified associations, either for producers, marketers or manufacturers where it is suffering from lack of qualified and effective employee, in addition, the absence of effective government efforts in the organization of this sector and its complementary sectors.

Problems and barriers of marketing olive and olive oil: As mentioned above it's very clear that the problems start with marketing at an early stage before the start of a long period where marketing influenced by a number of factors and transactions that take place before and during the production period. Among these obstacles lack of caring for trees and not care combating pests and insects and rely on rain water entirely in the field of irrigation and lack of attention to the process of supplemental irrigation and other practices that lead to impact on the quality of fruits and suitability for pickling and the quality of the oil extracted from them. The end of the production process picking process which requires a lot of manpower due to the nature of the fruits of which is characterized by its small size and spread on small branches and producers will be unable to acquire modern harvesting machines because of the high costs associated with the ownership of such machines. This pays producers to rely either on family members or seasonal employment which increased demand in this period wages rise. The labour shortage affects this on the duration of the harvesting process which extends in some countries for nearly two months, especially in large-scale farms.

Moreover, the lack of prior coordination between producers and owners of contemporary in an attempt by producers to reduce the cost of transportation store cut fruit until the harvest is complete. Besides in view of the limited potential for the vast majority of fruit producers are stored in unsuitable a condition which affects the fruit quality when converted to olive-oil and on the quality of the olive-oil extracted from them, also, the lack of suitable containers whether for marketing dates and olives or olive oil.

SWOT analysis: The SWOT analysis of the country's agriculture industry is made up of the literature review to show the sector potential against new entrants and its advantages over them.

Strength: Unique products and ingredients. A sound reputation of quality products, especially in Middle East countries. Ability to expand to supply base to meet sales. The labor force and the mechanical traction are relatively less expensive as compared to European competing countries.

Weakness: Developing a speculative spirit with a weak effort of prospecting, selection and market study and manifest lack of marketing strategies. Production alternation and low plantations productivity due to the drought and to the lack of upkeep, planning and restructuring olive oil plantations, particularly, senescent ones.

Absence of long-term strategy for the olive oil sector, horizontal and vertical integrations between the segments of the sector and as well as the absence of reserve stocks in olive oil and of mechanisms for encouraging and financing private storage and the absence of horizontal and vertical integration between the different areas of the sector which doesn't favor the engagement in a total quality program and limits the possibilities to reduce olive oil production cost. Weak efforts to preserve quality and increase the value of the product. Difficulty to make use of research and training acquirements in the sector which affects the qualification level of operator's Ad innovation effort predominance of the olive oil market in bulk and difficult to access funds which are generally unavailable.

A small proportion of the surface area of oil olive tree in irrigation. Raising the production cost of olive oil and raising the exportation cost of olive oil and the rigidity of the government regulation concerning olive oil exportation. Weak effort of markets prospecting, survey and selection, together with a manifest lack in marketing strategies for export and home markets. Concentration of the Libyan olive oil and dates exports in the global European and Union very little. Alternation of the production and limited plantation productivity due to the drought and the lack of maintenance, developing and restructuring of olive plantations, notably, senescent one. In spite of its adaptability to most difficult edaphic and climatic conditions, the olive tree is a genetically alternating crop.

\section{Opportunities}

Increase in worldwide specifically (European market) demand of olive oil and dates importation

Increase in the demand of olive oil and dates on the emergent markets such as the USA, Australia, Canada and Japan

\section{Threats}

- The emergence of new countries producers and exporters of olive Increasing health cautious society Increasing cost of ingredients 
- Bad media coverage of olive oil industry

- Increased government regulations in relation to hygiene and contents of ingredients

- Absence of long-term development strategy for the sector

This phenomenon is further aggravated in the arid and semi-arid regions due to the lack and unevenness of rains (torrential rains or successful dry years) and the bad quality of soils reserved to this crop in marginal zones lacking potentials or containing some damaged and un-conserved lands. The fluctuations of the olive product affect the productivity, the production cost, the income and account balance and result in an inability to reiterate this activity. From the driving analysis above, it can be summed the following is a review of the most important problems and limitations faced by the Libyan agricultural and industrial products and marketing of dates, olives and olive oil in Libya.

Overall problems and barriers facing Libyan agricultural and industrial products and marketing of dates, olives and olive oil in Libya: Agricultural product marketing in Libya facing many of the technical determinants which negatively affect the market, some of which occur in the pre-production stages and others get into the post-production stages and until the arrival of the product to consumers. The low efficiency of the staff working in the area are undeveloped and pickling and weakness and lack of expertise in the field of marketing. Also, the absence of promotional and educational programs which aimed at opening new markets on the one hand and to strengthen existing markets on the other.

Absence of marketing organizations came as the most important problem facing the agriculture and industry sector, perhaps intended is necessary legislation to establish such regulations and that if it was linked to the same problem and received at the department of technical problems rising relative importance of this problem and associated small holdings. Agricultural marketing systems in Libya still lack of sufficient knowledge of modern marketing which is based on knowledge of the needs and requirements of the market and consumers.

Libyan government was aware of this and it has been placing more attention to issues of marketing but these efforts are still without the required terms did not impair the development of marketing institutions has no adequate attention. The operations and marketing services are still in the process of first instance in the country Libya in terms of providing (processing) goods international standards and grades required quality and methods of packaging and storage, cooling and transport in addition, to the lack of information and low level of investment in research and development and market studies specialist and as a result of this lack of an increase in imports and exports fell.

Why the need of development: Agricultural and industrial sectors have great importance in the world economic and social dimensions, environmental and cultural. The economic importance lies in contributing to the gross national agricultural and agricultural exports on the one hand and the place occupied by the elements of food production and responsive to a part of the food requirements of the population and its contribution to the revenues of producers. And beyond that to the front and rear connect with other sectors and providing input to the output of these sectors as food processing sector which is the ground of agricultural production survival

Proposals to develop the production: In short, the focus here is on the majority of proposals for the development of production in Libya on 5 main themes is the development of practices in the field of production, the development of research, extension services, the development of regulations, legislation and incentives. The following is a breakdown of these themes.

In the field of promotion: Design and implementation of promotional programs for Libyan products in Foreign markets Encourage the holding of festivals and fairs specialized agricultural and industrial at the country level in order to promote local products internally and to educate and inform consumers the nutritional importance of the agricultural and industry and thus, contributing to the increased demand. Provide incentives for farmers to encourage them to land reclamation and planting olive trees.

In the field of research and development: Actually, this sector which is significantly important but unfortunately it has been lack of studies or database in this regard. They should provide all customers with the necessary information on the best methods of transportation, trading and care the information and specialized marketing studies on domestic and foreign markets. As well as improved methods of information distribution and delivery to farmers at the appropriate times.

Incentives: Stimulate Foreign investment in the agricultural sector through the provision of incentives and exemptions, particularly in the areas of manufacturing and marketing. Provide incentives for farmers and manufacturers to motivate them to improve the quantity and quality of production. 
In the area of market liberalization: Open the export of agricultural and industrial products to the Foreign markets to connect the domestic market to global markets which will reflect positively on the development of production quality to be able to compete and meet the requirements of the global market.

e-Shopping can play important role in such regard, internet marketing technology: Now a days, the internet playing an ever increasing role in reaching customers and sharing information about customers, marketing increasingly requires companies and individuals with technical expertise across a range of fields that know both marketing and internet technologies. Particularly as companies want to understand their customers better and develop new ways of partnering with customers using a wide range of interactive tools. More particularly, the internet is providing a key route for information, comment and feedback from customers to the supplier and between customers about the supplier whether from social networks, Apps, traffic analysis or new ways of inviting help from customers. In Libyan market case and in the short term, Libyan young leaders should bring agricultural and industrial production fully online by providing good internet channels and network tools and make it available to all who want to market his products online and by then the internet marketing sector system will resuscitate active and maintain macroeconomic stability.

\section{CONCLUSION}

Generally speaking, Libya faces the formidable challenges of responding to the underlying causes of the revolution and building a democratic regime in the midst of heightened regional risks and global uncertainties. Therefore, medium-term efforts should focus on capacity building, infrastructure renewal and private sector development, improving education, job creation and putting in place an effective social safety net within a framework of transparent and accountable governance. At the request of the Libyan authorities, international financial institutions are engaged in policy consultations and technical assistance, aimed at maintaining macroeconomic stability and developing an institutional infrastructure to promote economic diversification and employment growth. The new young Libyan government must face the new emerging globalization of domain names as many giant brand names become a reality and equally balance. There are many success stories, names only stay on top of the mind until the expensive fireworks come out. As we approach the global borderless future of multi-billion online users, global trademark registrability is the basic test to discover the limitations of a name. Diluted names cost a fortune in maintenance to stay alive.
Libyan leaders or corporation's should work hard on bringing to the light a unique product brand image as a step to approaches to differentiating which can be through several forms such as design etc. Whereas Muslim nation has very big opportunities among each other where they believe in each other in terms of Halal food issue where they majority of them have almost the same habits and culture it is believed that it's much better if they start corroborate with/among themselves as very early started by help each other and create an atmosphere for Muslim corporations and firms which will be the portal later on to the global market. In addition, Libyan government and administration as well as the organization's have to cooperate and coordinate with international firms which have long experience in the field of marketing. Above written case aimed to shed the light and critically analyse the related literature and by means of empirical investigation, further, the current understanding of global marketing meaning for Libyan creating new ways for future research. The lack of consistent definitions for different global marketing and the concept of marketing general, make it difficult to properly address and investigate the subject.

\section{REFERENCES}

Al-Idrissi, M., A. Sbeita, A. Jebriel, A. Zintani and A. Shreidi et al., 1996. Libya: Country report to the FAO international technical conference on plant genetic resources. Food and Agriculture Organization, Leipzig, Germany.

Anonymous, 2006. Socialist people's libyan arab jamahiriya: Country economic report. World Bank, Washington, USA. https://openknowledge. worldbank.org/handle/10986/23979License:CCBY3. OIGO.

Anonymous, 2015. Libyan Economy. World Development Indicators, North America.

Anonymous, 2016. Economy of Libya. The World Factbook, New York, USA. https://www.cia. gov/library/publications/the-world-factbook/geos/1 y.html

CFR., 2005. Libya Country Report: Childhood a Global Journal of Child Research. Council on Foreign Relations, New York, USA. https://www. slideshare.net/PetrBase/libya-country-report-2005.

EIA., 2014. Country analysis brief: Libya. Energy Information Administration, Washington, USA.

IMF., 2012. Global Recovery Stalls, Downside Risks Intensify. International Monetary Fund, Washington, USA. 